\title{
Cold Hardiness of Six Cultivars of Chinese Elm
}

\author{
Orville M. Lindstrom' \\ Department of Horticulture, University of Georgia, Griffin, GA 30223
}

\author{
Michael A. Dirr ${ }^{2}$ \\ Department of Horticulture, University of Georgia, Athens, GA 30602
}

Additional index words. woody ornamental, cold hardiness, acclimation, Ulmus parvifolia

\begin{abstract}
Cold hardiness levels of six cultivars of Chinese elm (Ulmus parvifolia Jacq.), 'Select 380', 'Orange Ribbon 740', 'Emerald Isle', 'Emerald Vase', 'Drake', and 'King's Choice', were determined over eight sample dates from 31 Aug. 1988 to 16 May 1989 and for 'Emerald Vase' and 'Drake', over three dates from 14 Feb. 1988 to 25 Apr. 1988. All cultivars tested achieved a maximum cold hardiness in December and January of -21 to $-24 \mathrm{C}$, except 'King's Choice', which survived exposure to at least - 30C. 'Emerald Isle' and 'Emerald Vase' acclimated earlier (both - 9C on 31 Aug.) and reacclimated later ( -6 and $-9 \mathrm{C}$, respectively, on 16 May) than other cultivars tested. 'Emerald Vase' and 'Drake' exhibited similar cold hardiness levels over the two years tested.
\end{abstract}

Chinese or lacebark elm is a promising drought- and heat-resistant landscape species with wide geographic adaptability (Byrnes, 1985; Keller and Weaver, 1982; Ward, 1985; Ware, 1985). It also has high resistance to elm leaf beetle (Hall and Young, 1986) and Dutch elm disease (Santamour, 1973). Chinese elm is considered hardy in zones 59 (Dirr, 1990; U.S. Dept. of Agr., 1990). One of its proposed niches is to replace the American elm (Ulmus americana L.), which has been popular throughout the United States (Whitcomb and Hickman, 1986).

The extreme variability of growth habit, leaf color, and texture and bark exfoliation of Chinese elm when grown from seed has precluded extensive nursery production and, thus, its use in the landscape. 'Drake' has been available since 1952 (Green, 1964) and is the most common nursery-grown cultivar. However, specimens of 'Drake' were killed in Oklahoma during a severe winter (Whitcomb and Hickman, 1986) and were also killed to the ground at Raleigh, N. C., in December and January $1984-85$ at -18 to - 23C (U.C. Raulston, personal communication). Limited information is available on the cold hardiness of specific cultivars, but 'Prairie Shade' and 'King's Choice' are reported to be more cold-hardy than 'Drake', the most commonly planted cultivar (Dirr and Richards, 1989; Whitcomb and Hickman, 1986). Cold hardiness information is critical to the nursery industry to expand the usage of Chinese elm cultivars into the northern regions of the United States and Canada.

Received for publication 1 June 1990. This research was supported in part by a grant from the Horticultural Research Institute (HRI). The cost of publishing this paper was defrayed in part by [he payment of page charges. Under postal regulations, this paper therefore must be hereby marked advertisement solely to indicate this fact.

${ }^{1}$ Assistant Professor.

${ }^{2}$ Professor.
Lindstrom and Dirr (1989) found that taxa exhibiting the greatest midwinter cold hardiness do not necessarily have the greatest cold hardiness earlier in the fall and later in the spring. They proposed that evaluating the cold hardiness during the fall, winter, and spring would give a better representation of the overall cold hardiness than would a single midwinter determination.

This study determined the level of cold hardiness of the stems of several Chinese elm selections at intervals throughout fall, winter, and spring using a laboratory freezevaluated in mid-Winter and Spring 1988, while 'Select 380', 'Orange Ribbon 740', 'Emerald Isle', and 'King's Choice' were evaluated in Fall, Winter, and Spring 198889.

During the first year of the study, stems of 'Emerald Vase' were collected from an 80-year-old tree at Athens, Ga., on 14 Feb., 17 Mar., and 25 Apr. 1988, while 'Drake' was collected only on 17 Mar. from 2-yearold nursery plants. During the fall, winter, and spring of the 2nd year of the study (198889 season), 'Emerald Vase' was collected from the same 80-year-old tree, while 'Emerald Isle' was collected from a 65-year-old tree at Athens. 'Drake', 'Select 380', 'Orange Ribbon 740', and 'King's Choice' were collected from 2-year-old nursery stock at Athens. All cultivars were collected on 31 Aug., 4 Oct., 16 Nov., 1 Dec., 19 Jan., 15 Mar., 12 Apr., and 16 May. 'Orange Ribbon 740 ' was not collected after 19 Jan. because the plant was removed from the nursery. The nursery plants were grown under trickle irrigation and were provided $\mathrm{N}$ at 560 $\mathrm{kg} \cdot \mathrm{ha}^{-1} \cdot$ year $^{-1}$. In the fall and early spring, granular $12 \mathrm{~N}-5.3 \mathrm{P}-10 \mathrm{~K}$ was applied at 933 $\mathrm{kg} \cdot \mathrm{ha}^{-1}$. During the late spring and summer, a total of $2100 \mathrm{~kg}$ of $16 \mathrm{~N}-1.8 \mathrm{P}-6.6 \mathrm{~K}$ liquid fertilizer/ha was supplied through a drip irrigation system. Average weekly temperaing test. 'Emerald Vase' and 'Drake' were tures and total weekly precipitation for the Athens area (National Weather Service, Southeastern Agricultural Weather Service Center, Auburn, Ala.) are presented in Fig. 1

Twenty-four uniform, 10-cm-long stem tips were removed from each plant on each test day. Leaves, if present, were removed. Samples, wrapped in wet paper towels, were put in plastic bags then placed on ice for transport to Griffin, Ga. The stem tips were prepared for the freezing test within $4 \mathrm{~h}$ of collection. The terminal $7 \mathrm{~cm}$ of each stem was removed, wrapped in moist cheesecloth, and placed into a test tube $(25 \times 200 \mathrm{~mm})$. The tubes then were submerged in a 1 ethylene glycol : 1 water solution in a Forma Scientific Model 2425 temperature bath (Forma Scientific, Marietta, Ohio) precooled to $-1.5 \pm 0.5 \mathrm{C}$. Stem temperatures were measured by means of thermocouples (Type T; Omega Engineering, Stamford, Corm.) placed next to the stem and recorded by a Campbell Scientific data logger (Model CR7-X; Campbell Scientific, Logan, Utah). Crushed ice crystals were applied to the wet cheesecloth to ensure that stems did not undercool and that the temperature of the stems was held constant at $-2 \pm 0.5 \mathrm{C}$ for $\approx 14$ h. Samples were then cooled at a rate of 3.8 $\pm 0.2 \mathrm{C} / \mathrm{h}$. Four stems of each taxon were removed from the bath at progressively lower $3 \mathrm{C}$ temperature intervals. Controls were prepared and kept on ice for the duration of the freezing test.

After thawing on ice, the samples were removed from the tubes and placed in disposable, round, $100 \times 15-\mathrm{mm}$ petri dishes containing filter paper saturated with water (100\% relative humidity). The petri dishes were placed on their sides in the dark at room temperature $(22 \times 2 \mathrm{C})$ for 10 to 14 days, when the stems were visually evaluated for injury as described by Fuchigami et al. (1971), Hummel et al. (1982), Smithberg and Weiser (1968), Stergios and Howell (1973), and van Huystee et al. (1967). Segments showing brown discoloration and breakdown of cells in the cambium and phloem were rated as dead. The controls and stems not injured by the freezing treatments remained green and showed no discoloration in the cambium or phloem. The number of stems killed at each temperature was recorded, and from these data, the lowest survival temperature (LST) was determined using Fisher's exact test on sequential $2 \times 2$ contingency tables (SAS Inst., 1985). The LST is the lowest temperature at which little or no injury was observed, as described by Sakai et al. (1986). In all but two cases, there was no variability among replicates when we determined the LST for a specific cold-hardiness test. Where variability was present (two cases), it was $\pm 1.5 \mathrm{C}$ or less. Therefore, the LST values can be treated as constants and no further statistical analysis is necessary. The lack of variation between replicates can be explained since cultivars were used that, by their nature, are uniform and cold hardiness was determined only within a $3 \mathrm{C}$ range. The low-temperature limit of the temperature bath 
Table 1. Lowest survival temperature (LST) of six Ulmus parvifolia cultivars evaluated from 31 Aug. 1988 to 16 May 1989. All LST determinations can be treated as constants since there was, in all but two cases, no variation among the replicates used to determine the LST. In the two cases where variation existed, the standard deviation is indicated.

\begin{tabular}{|c|c|c|c|c|c|c|c|c|}
\hline \multirow[b]{3}{*}{ Taxon } & \multicolumn{4}{|c|}{1988} & \multicolumn{4}{|c|}{1989} \\
\hline & 31 Aug. & 4 Oct. & 16 Nov. & 1 Dec. & 19 Jan. & 15 Mar. & 12 Apr. & 16 May \\
\hline & \multicolumn{8}{|c|}{$\mathrm{LST}\left({ }^{\circ} \mathrm{C} \pm 0.5\right)$} \\
\hline Select 380 & -3 & $-6^{z}$ & $-15^{y}$ & $-24^{y}$ & -21 & $-15^{x}$ & $C^{w}$ & $\ldots v$ \\
\hline Orange Ribbon 740 & $C^{*}$ & -6 & $-15^{y}$ & $-24^{y}$ & -21 & -.- & $-\cdots$ & ..- \\
\hline Emerald Isle & -9 & -9 & -12 & $-24^{y}$ & -24 & -21 & -12 & -6 \\
\hline Emerald Vase & $-9^{2}$ & -9 & -9 & -21 & -21 & -18 & -9 & -9 \\
\hline Drake & $\mathrm{C}^{\mathrm{w}}$ & $C^{w}$ & $-15^{y}$ & $-24^{y}$ & -24 & $-15^{x}$ & $\mathrm{C}^{\mathrm{w}}$ &.- \\
\hline King's Choice & -3 & -6 & $-15^{y}$ & $-24^{y}$ & $<-30$ & $-15^{x}$ & $\mathrm{C}^{w}$ & $\ldots$ \\
\hline
\end{tabular}

${ }^{x}$ Standard deviation, $\pm 1.5 \mathrm{C}$.

ySamples survived exposure to lowest temperature on this datc.

xSamples killed at this temperature, no samples were removed between this temperature and control on this date.

"Only control survived.

"No data.

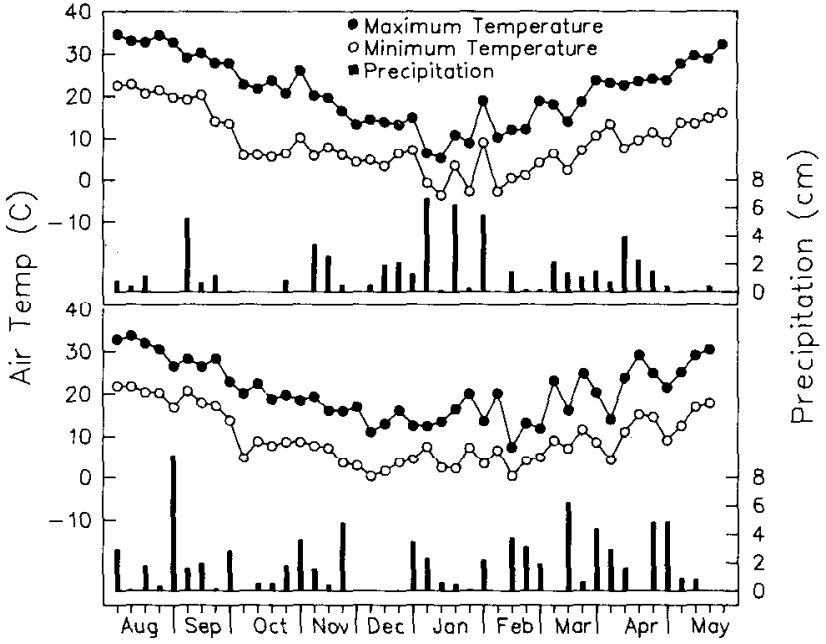

Fig. 1. Weekly precipitation accumulation and maximum and minimum temperatures for Aug. 1987 through May 1988 (top) and Aug. 1988 through May 1989 (bottom) for Athens, Ga.

was - 30C; therefore, several taxa in midwinter were not killed and are reported as having a LST of $<-30 \mathrm{C}$.

No cultivar was consistently the most coldhardy over all sample dates. 'King's Choice' exhibited the greatest midwinter cold hardiness (January) of the cultivars tested, while 'Emerald Isle' and 'Emerald Vase' were the most cold-hardy during early fall (August, October) and again later in the spring (March to May) (Table 1). 'Emerald Isle', 'Emerald Vase', 'Select 380', 'Orange Ribbon 740', and 'Drake' exhibited similar (to one another) midwinter cold hardiness levels, but in January, were at least 6 to $9 \mathrm{C}$ less coldhardy than 'King's Choice'. 'Select 380', 'Orange Ribbon 740', and 'King's Choice' developed cold resistance at an earlier date than 'Drake', which exhibited no cold resistance as late as 4 Oct. 'Drake' was also among the least cold-hardy of the cultivars on 15 Mar. and showed no cold hardiness in April.

'Emerald Vase' showed similar levels of cold hardiness on similar dates in 1988 and 1989 (Tables 1 and 2) even though the ambient temperature varied from year to year (Fig. 1). 'Drake' also exhibited similar levels of cold hardiness on the two March dates of 1988 and 1989 (Tables 1 and 2).

The LST in midwinter is a major factor in selecting cultivars for their potential adapt- ability to northern latitudes, but developing a level of cold hardiness earlier in the fall and maintaining it later in the spring is also advantageous. The data show that 'Emerald Isle' and 'Emerald Vase' harden early in the fall and reacclimate late in the spring. Thus, these cultivars maybe well adapted to northern latitudes. 'Drake' developed similar midwinter cold hardiness to the other nursery-grown plants but acclimated later and reacclimated earlier. This pattern may explain the inability of 'Drake' to adapt to cold climates. Direct comparisons between the older trees, 'Emerald Isle' and 'Emerald Vase', and the younger nursery-grown trees, such as 'Drake', should be used with caution since the age of the tree may influence their cold tolerance (Levitt, 1980). Other studies are needed to verify whether these same acclimation/deacclimation patterns will occur when these plants are grown in more northern areas.

The cultivars tested may not have reached maximum midwinter cold hardiness under Georgia conditions since sufficient low temperatures may not have occurred to maximize cold-hardiness potential (Weiser, 1970). Therefore, the cold-hardiness levels of the cultivars may increase if grown in more northern latitudes. Numerous seed-grown trees of Chinese elm are present throughout the
Table 2. Lowest survival temperature (LST) of two Ulmus parvifolia cultivars evaluated from 14 Feb. to 25 Apr. 1988. All LST determinations can be treated as constants since there was no variation between the replicates used to determine the LST.

\begin{tabular}{|c|c|c|c|}
\hline \multirow[b]{2}{*}{ Taxon } & 14 Feb. & 17 Mar. & 25 Apr. \\
\hline & \multicolumn{3}{|c|}{$\operatorname{LST}\left({ }^{\circ} \mathrm{C} \pm 0.5\right)$} \\
\hline $\begin{array}{l}\text { Emerald Vase } \\
\text { Drake }\end{array}$ & $\begin{array}{l}-27 \\
\cdots\end{array}$ & $\begin{array}{l}-18 \\
-12\end{array}$ & $\begin{array}{l}-9 \\
-\cdots\end{array}$ \\
\hline
\end{tabular}

${ }^{2}$ No data.

southeastern United States and offer a diverse source of germplasm. A screening method to identify specific clones with a substantial degree of cold hardiness is needed. We suggest that a seasonal low-temperature tolerance profile be included in the estimation of a new cultivar's geographic adaptability.

\section{Literature Cited}

Byrnes, R.L. 1985. Cultivar trees for North Central Florida. Proc. Fla. State Hort. Soc. 98:308309

Dirr, M.A. 1990. Manual of woody landscape plants. 4th cd. Stipes Publishing Co., Champaign, Ill.

Dirr, M.A. and A.E. Richards. 1989. In search of the perfect Chinese elm. Amer. Nurseryman 169(2):37-43.

Fuchigami, L. H., C.J. Weiser, and D.R. Evert. 1971. Induction of cold acclimation in Cornus stolonifera Michx. Plant Physiol. 47:98-103.

Green, P.S. 1964. Registration of cultivar names in Ulmus. Arnoldia 24:41-80.

Hall, R.W. and C.W. Young. 1986. Host suitability of three Asiatic elms to the elm leaf beetle (Xanthogaleruca luteola) (Coleoptera: Chrysomelidae). J. Env. Hort. 4:44-46.

Hummel, R. L., P.D. Ascher, and H.M. Pellett. 1982. Inheritance of the photoperiodically induced cold acclimation response in Cornus sericea L., Red-osier dogwood. Theor. Appl. Genet. 62:385-394

Keller, G. and R.E. Weaver, Jr. 1982. Replacing the American elm: Twelve stately trees. Arnoldia 42:88-100.

Levitt, J. 1980. Response of plants to environmental stresses. 2nd ed. Vol. I: Temperature stress. Academic, New York. p. 152.

Lindstrom, O.M. and M.A. Dirr. 1989. Acclimation and low temperature tolerance of eight woody taxa. HortScicnce 24:818-820.

Sakai, A., L. Fuchigami, and C.J. Wciser. 1986. 
Cold hardiness in the genus Rhododendron. J. Amer. Soc. Hort. Sci. 111:273-280.

Santamour, F. S., Jr. 1973. Resistance to Dutch elm disease in Chinese elm hybrids. Plant Dis. Rptr. 57:997-999.

SAS Institute. 1985. Users guide statistics, Version 5 ed. SAS Inst., Inc., Cary, N.C.

Smithberg, M.H. and C.J. Weiser. 1968. Patterns of variation among climatic races of red-osier dogwood. Ecology 49:495-505.
Stergios, B.G. and G.S. Howell, Jr. 1973. Evaluation of viability tests for cold stressed plants. J. Amer. Soc. Hort. Sci. 98:325-330.

U.S. Department of Agriculture. 1990. Plant hardiness zone map. U.S. Dept. Agr. Misc. Publ 1475.

van Huystee, R. B., C.J. Weiser, and P.H. Li. 1967. Cold acclimation in Cornus stolonifera under natural and controlled photoperiod and temperature. Bet. Gaz. 128:200-205.
Ward, J.D. 1985. Chinese elm: A source of confusion for nurserymen and landscapers. Proc. Fla. State Hort. Soc. 98:305-306.

Ware, G. 1985. Urban trees and shrubs for the midwest from the Morton Arboretum. Amer. Nurseryman 161(9):4246.

Weiser, C.J. 1970. Cold resistance and injury in woody plants. Science 169:1269-1278.

Whitcomb, C.E. and G.G. Hickman. 1986. 'Prairie Shade' Elm. HortScience 21: 162-1 63. 